\title{
As exigências da Cacex na concessão de financiamentos à exportação
}

Lincoln de Souza Chaves, consultor jurídico da Carteira de Comércio Exterior do Banco do

\author{
Lincoln de Souza Chaves
}

Nos financiamentos concedidos à exportação pela Cacex são exigidos quatro tipos de garantia. A exemplificação baseia-se nos contratos de financiamento de navios, a saber: hipoteca; aval das cambiais; letter of quaranty, emitida por banco de primeira linha; e seguro de crédito à exportação.

Apesar dessas garantias, registram-se certas

dificuldades no adimplemento das obrigações por parte dos importadores estrangeiros. A carta de garantia tem sido em geral o tipo mais eficaz. O Banco do Brasil financia a exportação com dinheiro público e, assim, não pode facilitar na obtenção dessas garantias, sob pena de expor a sérios danos a economia nacional e as próprias partes na operação, além de outras consequeências.

\section{O papel do Banco Central no contexto das exportações. O Fundo de Financiamento à Exportação - Finex.}

Sílvio Hitoshi Yanagawa, consultor jurídico do Banco Central do Brasil
Sívio Hitoshi Yanagawa
Instituído no Banco Central do Brasil pela Lei n. 5.025 e administrado pelo Banco do Brasil, o Finexé a estrutura fundamental no financiamento das exportações. Cumpre ao Banco Central; entre outras atribuições, tornar líquido e bom o crédito às exportações, missão em que encontra certas dificuldades.

A primeira refere-se ao valor da moeda em que é feita a exportação - para fugir às moedas fracas, estipula-se, como moeda de pagamento, o dólar ou outra moeda forte. Ora, realizada a exportação e descontados os títulos pelo-Finex (que, em última instância, é quem banca em nome do governol, se o financiamento foi contratado a médio e longo prazos, a própria moeda escolhida para a exportação, ainda que forte, está sujeita aos efeitos da inflação do respectivo país. Trata-se, então, de risco sem qualquer cobertura de seguro.

Outro problema concerne à crise cambial dos países importadores. Não basta exportar simplesmente; urge receber o produto dessa exportação. $E$ não são poucos os países, nestes dias conturbados, que estão em fase de reescalonamento de dividas. Na salvaguarda dos ativos nacionais, todas as diligências são desenvolvidas pelo Banco Central, cogestor do Finex; o Itamaraty, que possui divisão especializada na matéria; e outras autoridades do governo. 